\title{
Radiation Therapy Recipient
}

National Cancer Institute

\section{Source}

National Cancer Institute. Radiation Therapy Recipient. NCI Thesaurus. Code C156403.

An individual receiving radiation therapy. 